\section{DIGITAL COMMONS \\ @ UNIVERSITY OF SOUTH FLORIDA}

\section{ABO: Interactive Journal for Women in the Arts, 1640-1830}

Volume 5

Issue 1 Volume 5.1 (Spring 2015)

Article 7

2015

\title{
Review of Helen E.M. Brooks, Actresses, Gender, and the Eighteenth-Century Stage: Playing Women
}

Leslie Ritchie

Queeens University, Canada, leslie.ritchie@queensu.ca

Follow this and additional works at: https://digitalcommons.usf.edu/abo

Part of the Dramatic Literature, Criticism and Theory Commons, Educational Methods Commons, Feminist, Gender, and Sexuality Studies Commons, and the Literature in English, British Isles Commons

\section{Recommended Citation}

Ritchie, Leslie (2015) "Review of Helen E.M. Brooks, Actresses, Gender, and the Eighteenth-Century Stage: Playing Women," ABO: Interactive Journal for Women in the Arts, 1640-1830: Vol.5: Iss.1, Article 7. http://dx.doi.org/10.5038/2157-7129.5.1.6

Available at: https://digitalcommons.usf.edu/abo/vol5/iss1/7

This Reviews is brought to you for free and open access by Digital Commons @ University of South Florida. It has been accepted for inclusion in ABO: Interactive Journal for Women in the Arts, 1640-1830 by an authorized administrator of Digital Commons @ University of South Florida. For more information, please contact digitalcommons@usf.edu. 
Review of Helen E.M. Brooks, Actresses, Gender, and the Eighteenth-Century Stage: Playing Women

\section{Keywords}

actress, maternity, gender, breeches, travesty, Dorothy Jordan, Sarah Siddons, Margaret Woffington

\section{Creative Commons License}

(c) $($ ) $\odot$

This work is licensed under a Creative Commons Attribution-No Derivative Works 3.0 License. 
Helen E.M. Brooks. Actresses, Gender, and the Eighteenth-Century Stage: Playing Women. Basingstoke: Palgrave Macmillan, 2015. X + 176. Index. ISBN 978-0-230-29833-0.

Reviewed by Leslie Ritchie

Queen's University, Canada

In her book, Actresses, Gender, and the Eighteenth-Century Stage: Playing Women, Helen Brooks argues that in "the last decades of the eighteenth century, public discourse around actresses focused increasingly on their subscription to idealised, bourgeois femininity, as demonstrated through their embodiment of the domestic roles of wives, daughters, and ... mothers" (3). This concept is immediately illustrated by a photograph of the memorial of 'Mrs Jordan' by Sir Francis Chantrey (1834). This monument, now in the Royal Collection, depicts the actress breast-feeding an infant, with the mask of comedy lying discarded at her feet. Brooks reads this image as suppressive of Jordan's identity as actress, and writes in favour of a more valenced interpretation of actresses' identities, reflective of their responses to emerging and rapidly changing models of femininity: "by locating actresses in an anomalous relationship to mainstream society and womanhood we risk obscuring their important place as professionals, economic agents, theatrical innovators, and . . f figures within women's history" (5). The figures chosen for her study are "successful and celebrated" London actresses (11), and the study stages comparisons of different actresses' responses to gender constructs at particular times rather than pursuing a chronological progression. Indeed, the study's chapter titles ("Playing for Money"; "Playing the Passions"; "Playing Men"; "Playing Herself"; "Playing Mothers") seem to negate the possibility or desirability of any stable feminine identity for actresses.

One of the most commendable aspects of this book is its attention to money: not just to reporting actresses' salaries and benefits, but considering, too, the actresses' attitudes towards their earnings and their most valuable roles. Dorothy Jordan bares considerable economic ambition, writing, "I should be content with less applause and more money" (qtd. on 16), to her lover, the Duke of Clarence, from Edinburgh in 1810. Though one wonders if Jordan's candid desire for "more money" might also be read as an appeal to the letter's recipient, Brooks' point here and throughout the chapter is that the stage was "one of the only fields in which [women] could, through their own independent labour, make not just a living, but potentially a fortune" (41), and that any discussion of actresses' agency should include an examination of how that agency was exerted in negotiating theatrical contracts. Particularly insightful here is Brooks' admonition that we 
should not assume "that systematic inequality in remuneration translates into individuals being consistently disenfranchised or disaffected" (emphasis added 23).

The book's visual images are well chosen, and they are often used in a suggestive way. In the third chapter, "Playing Men," a reference to Hannah Snell's success in passing as a man ("James Gray") while in the army is accompanied by a portrait of Snell in military dress. The image invites the reader to consider not just Snell's success in passing, but the larger possibility of actresses achieving a stage masculinity so successful that it might overturn heteronormative audience response, as Brooks suggests it did when Peg Woffington apparently caused men to "envy her masculinity, and the women [to] gaze on with desire" (76). This is an interesting development of the familiar idea that breeches roles and travesty roles chiefly excite the pleasure of discerning the performer's true gender under the performed role and the masculine costume. Brooks associates this idea only with breeches roles. Travesty roles (in which a female actress plays a male character in the drama), Brooks argues, "celebrated and foregrounded the mutability of sexual identity" (64); breeches performances (roles in which female characters disguise themselves as men within the play), however, "focused more often on the 'truth' of the character's sexual identity beneath the disguise, [and] resisted this gender play" (65).

The fifth chapter, "Playing Mothers," examines Sarah Siddons' conscious shaping of her dramatic persona to encourage audiences to see her dramatic performances of tragic mothers as expressive of her authentic maternity (118), an argument that builds logically on an earlier chapter's assertion that Siddons policed her behavior in social situations so as to elide any "gap between her social and dramatic expression, encouraging audiences to read the former both through, and in, the latter" (113). In Siddons' case, dramatic self-fashioning included employing her own son as her stage son in a 1782 production of Isabella; or The Fatal Marriage. Here, more discussion of the portrait of "Mrs Siddons \& Henry Siddons in Isabella or the Fatal Marriage by David Garrick" by William Hamilton, ca. 1785, helpfully included, might have proved illuminating. While the play's text suggests that Isabella sees the look of the child's father in his face, as Brooks writes (121), the viewer of both the play and the portrait views not an image of paternity, but one of maternity, for the image of the actress is clearly reflected in the similar nose, eye line, brows, and lift of young Henry Siddons' jaw. Discussing the popularity and circulation of prints of this image would only have strengthened 
the case for Siddons' success in exploiting her culture's newfound obsession with maternity.

The financial margins of the academic publishing industry and the pressure to publish can exert a squeeze at the copy-editing stage of publication. Without knowing what the copy-editing procedure at Palgrave Macmillan is, one can still regret the presence of such textual errors as "helpless in the face of a righteousness God" (53) and "Pregnancy in its physically manifestation" (117), the misspellings "accursation" and "Scioltio" (79), or the substitution of "reigns" for "reins" (129). Even good editors need good editors.

The book lacks a formal conclusion, and thus unfortunately misses the chance to summarize its contributions to scholarship, and to tie its chapters together cohesively, though its other formal apparatus (an index of persons, places, and concepts; and a bibliography, divided into manuscripts and published works) does show evidence of considerable research. Perhaps the lack of closure may be read as a gesture to the study's commitment to seeking out varying models of femininity, and to its refusal to establish one model of femininity, or one type of response to any given feminine ideal as normative on the part of actresses.

In its promising look at maternity, and in its consideration of actresses' varying adaptations to eighteenth-century ideals of femininity, this volume contributes to the growing field of recent work concerning actresses' identities during the long eighteenth century, including works by Felicity Nussbaum, Laura Engel, Gilli Bush-Bailey, Elizabeth Howe, Jean Marsden, Cynthia Lowenthal, Fiona Ritchie, and others. In its focus on celebrated actresses, it draws nearest Nussbaum's detailed book, Rival Queens: Actresses, Performance, and the Eighteenth-Century British Theater (University of Pennsylvania Press, 2010) though Nussbaum's later chapters present structured studies of individuals (Catherine Clive, Margaret Woffington, Frances Abington), whereas Brooks' chapters are more broadly thematic. Fiona Ritchie's recent book, Women and Shakespeare in the Eighteenth Century (Cambridge, 2014), also nicely complicates received notions of actresses Dora Jordan and Sarah Siddons, though with an eye to showing their contributions to the creation of Shakespeare as the national bard. Laura Engel's book, Fashioning Celebrity: Eighteenth-Century British Actresses and Strategies for Image Making (Ohio State University Press, 2011) likewise considers Siddons, though with more focus on her diva-like queenliness than on her maternity as the principal driver of her celebrity. Brooks' subject is wellpositioned to contribute to this lively area of inquiry, and we look forward to her future work in this field. 